\title{
Bonbons and Bayonets: Mixed Messages of Childhood in the Late Ottoman Empire and the Early Turkish Republic
}

\author{
Benjamin C. Fortna
}

This chapter explores the conflicted nature of Ottoman and Turkish childhood that emerges from a reading of children's reading materials, including textbooks and magazines produced during the period from the 1880 s to 1930. It argues that, as was the case in Western Europe and many other places around the world, the image of childhood was constructed at the confluence of a number of competing agendas in the political, social, economic and cultural spheres. Drawing mostly on children's reading materials produced both by the state and private actors, the chapter explores the tensions, contradictions and mixed messages with which primarily Turkish Muslim children were confronted in the late Ottoman and early Turkish Republican eras. In particular, it examines the contrast between a fanciful, cartoonish world of sweets, dolls and games and the stark world of warfare, sacrifice and service to the homeland, first the empire and then the nation. The dramatic military conflicts and political developments of the period that saw the demise of empire and the emergence of a nation state can, paradoxically, be seen to have been both crucial and surprisingly inconsequential in the shaping of children's lives. The complexities and contradictions of an age in flux help to explain the conflicting expectations which children in this period had to face in order to turn adult conceptions of childhood into their own lived reality.

\section{Introduction}

Childhood is almost always understood in different and contradictory ways. It is experienced; that is to say, lived variously, remembered distortedly and conceptualized imperfectly. Conceptions of childhood and youth have varied significantly over time and across cultural and geographical space, reflecting the larger social, cultural and economic forces at play. To take one prominent example, the contrasting mythologized Apollonian and Dionysian understanding of youth identified by Chris Jenks reveal a fundamental difference in the way adults view 
the young. ${ }^{1}$ The Dionysian child is thought to be fundamentally bad, both impish and corrupting, and thus requires adult supervision to correct his or her destructive tendencies. The Apollonian child, by contrast, is understood to be inherently good, innocent and angelic, but his or her innocence requires adult intervention to allow the child's intrinsic creativity the time to develop and mature. What is interesting for the discussion here is the fact that both views depend upon a fundamental boundary between childhood and adulthood, one that in many locales had been erected only fairly recently in historical time as the understanding of the 'new' child came into being. Both views are, not surprisingly, adult projections about what childhood should be in its ideal state. Those projections have proved remarkably powerful but are themselves often tempered by real-life conditions. As Philippe Ariès famously recognized, across historical time most parents did not conceive of their children as inhabiting a separate stage of life delineated by the term 'childhood.' ${ }^{2}$ Even when in the relatively recent past this began to change and young people came to be seen as and even defined by inhabiting a distinct phase of life, many parents could not afford the luxury of treating their offspring as if their youth isolated them from the realities of adult concerns, economic ones first and foremost.

While adult recognition of the category of childhood was coming into being, the lives onto which adults projected their types and concerns were of course inherently varied. A recent publication offering translations of a range of early memoirs from the late Ottoman Empire and the early Turkish Republic underscores this diversity. Even though the fact of authorship, and with it the access to the literacy and education necessary to compose such reminiscences, entails a fairly drastic reduction in the possibilities for representativeness of the sample, the lives conveyed in this collection are nevertheless remarkably diverse with respect to gender, geography, religion, social background and psychological composition. ${ }^{3}$ The linguistic, ethnic and cultural richness of the late Ottoman Empire not surprisingly ensured that its children lived and subsequently remembered their childhoods in a variety of different ways. This diversity of experience notwithstanding, a clear pattern emerges from an investigation of the ways childhood was conceived and represented by adults. In the late Ottoman and immediate post-Ottoman periods-times of especially acute upheaval, stress and anxiety in both family and imperial/national life-we can

1 Chris Jenks, Childhood (2nd edition, London: Routledge, 1996), 7off.

2 Philippe Ariès, Centuries of Childhood: A Social History of Family Life, translated by Robert Baldick (New York: Vintage, 1962).

3 Klaus Kreiser and Patrick Bartsch (eds.), Türkische Kindheiten ([Frankfurt am Main:] Literaturca, 2012). I thank Philipp Wirtz for bringing this work to my attention. 
detect both a tendency to shelter children from the 'real world' and, contradictorily, an imperative that children should engage with the world in order to improve and shape it. In fact, as we shall see, some adults were keen to assign children the burden of saving the nation.

Times of particularly acute stress perhaps naturally generate a degree of anxiety that places heightened demands on infancy and youth. The upheavals and dislocations associated with the demise of the Ottoman Empire and the appearance of the nationally defined states that replaced it demonstrate these contradictions in especially sharp relief. Given inter alia the unprecedentedly rapid pace of change in almost all spheres of life-the effects of warfare, including the dramatic demographic shifts that frequently followed in its wake, the sometimes abruptly changing ideology of the state and the increasing penetration of public education with a concomitant rise in literacy and the dissemination of textsthis period placed particularly strong demands on its children. How childhood was imagined, how it should be molded, the roles that the family and the teacher ought to play in it, and the extent to which it was conceived as both a distinct and a fully integrated part of first imperial and then national life: all were being affected by the stresses generated by the break-up of the Ottoman Empire and the coming into being of nation states in its stead.

\section{Bonbons}

This heightened atmosphere exaggerated the pre-existing tendency to create two distinct worlds of childhood. The first, referred to here in shorthand as the world of 'bonbons,' is a realm of idealized, romanticized and proto-Disneyesque fantasy. In this construction children are protected and isolated from adult concerns. In the literature produced for children that was rapidly creating its own publishing niche from the 188 os onwards children are frequently depicted as being dependent on the wisdom, bounty and prescience of their elders but otherwise isolated from the preoccupations of the grown-up world, quite like their counterparts in the West. ${ }^{4}$

The first sign that this world was one that treated children as distinctly different from adults appears in the way that the adult interlocutors address the children in these texts. The introductions and opening lines of many of the books and magazines catering to a young readership would frequently feature passages in which children were spoken to in patronizing terms, such

4 Hugh Cunningham, Children and Childhood in Western Society since 1500 (London: Longman, 1995), 1. 
as "my dears" or "my little ones." The children inhabiting this world are said to possess 'mini-mini brains' and appear to be completely dependent upon the world of adults for protection, sustenance and moral guidance. Such forms of address, while perhaps intended to be affectionate, nevertheless establish an unmistakable hierarchical barrier between the active adult authorial voice and the passive child audience. Defining the roles so clearly in this way set the tone for the content that was to follow in these texts.

Sometimes children are depicted as merely mouthing the words of adults, giving a stilted and scripted aspect to their utterances. This combination of ventriloquism and wishful thinking produced images such as that displayed on the cover of one edition of the children's magazine Gürbüz Türk Çocuğu [The Healthy Turkish Child]. ${ }^{5}$ Two young children are shown next to an easel supporting a blackboard. One of the children has a piece of chalk in hand; the text beside them reads: "Every nation's level of civilization is connected to the importance and attention paid to its children." These are hardly the words to be spoken, let alone written, by children still to lose their baby fat. Putting words into the mouths of children was consonant with a widespread strategy aimed at framing their world in adult terms.

Similarly idealized but presented as natural was the range of activities in which children were represented. Whether depicted in the process of learning or playing, children were shown in a range of stilted, demonstrational poses reflecting an adult fantasy of childhood. This cocooned conception represented children both visually through the increasingly widespread use of illustrations and verbally as being engaged in a heavily idealized set of activities. Such scenes mostly show little or nothing in the way of context. Rather, they depict generically rendered children busy in the abstract projections of their adult authors and illustrators. Whether playing games, reading or frolicking with a variety of fluffy animals, the children shown in these images are invariably devoid of the normal markers of time and space that would indicate a localized context for children's activities.

In fact, this world is so far removed from reality that it blends readily into fantasy. Animals that can speak, perform mathematical calculations and deploy elaborate mechanical contraptions populate the reading materials that were increasingly available for children. Indeed, many of these new publications included cartoon drawings, underscoring their fictional nature. In this world readers encounter a talking horse, a lamb much like Bo-Peep who accompanies a child to school and the duelling antics of a fox and rabbit who use elaborate mechanical devices to gain the upper hand over their adversaries. Anthropomorphism plays a

5 Gürbüz Türk Çocuğu [The Healthy Turkish Child] April 23, 1927. 
central role; animals are frequently given human-like faces and expressions. Perhaps the ultimate expression of this fantastic dimension is the category of stories and illustrations that portray adventures in outer space, complete with rockets and space travellers. These hyper-fictionalized scenes represent the ultimate representation of an escapist tendency in the depiction of children's activities in these sources. For example, the children's magazine Yeni Yol offered a story in which two boys were each encouraged to choose a book and to read it on their own at school. One of the boys opts for a Jules Verne-like tale that contains an account of lunar travel and the discovery of a new celestial body. ${ }^{6}$ In an era increasingly exposed to and interested in the possibilities afforded by newly developing technologies such as rapid transport and new modes of communication by land, sea and air, ${ }^{7}$ it was perhaps not surprising that children's literature would engage with the more imaginative - and entertaining — end of the spectrum.

Even the school, the most common, grounded, everyday element on display in characterizations of childhood, could be portrayed as a highly artificial realm. In both the late Ottoman and early Turkish Republican periods the educational institution was cloyingly depicted as a joyful world where grateful children appreciated and even eulogized their schools and teachers. In these texts, children are made to do all sorts of unlikely things in order to conform to adult projections of an idealized childhood. Two examples convey the lengths to which children's authors went in trying to concoct an idealized fondness for school. The first, a poem by the celebrated author and educationalist Tevfik Fikret (1867-1915) takes the form of a dialogue between a girl named Şermin and her grandmother. Understandably one of the great poet's little-known works, the poem details in highly stilted terms the things that its young female protagonist Şermin loves the most. After mentioning the members of her family she dwells on her favorite sweets, such as rice pudding, candy and pastry,

But most of all I love my school,

My school I love very much

Beautiful building!

What things it teaches me. ${ }^{8}$

6 Yeni Yol 50, 13 Teşrin-i sani 1340 [November 13, 1924], 417.

7 For a discussion of the importance of the new as represented by technology in the late Ottoman period, see Palmira Brummett, Image and Imperialism in the Ottoman Revolutionary Press, 1908-1911 (Albany, NY: SUnY Press), 289 ff.

8 Sadrettin Celal, Cümhuriyet Çocuklarına Sevimli Kırâat (Istanbul: Kanaat Kütüphanesi, 1928), 9-10. For further details, see Benjamin C. Fortna, Learning to Read in the Late Ottoman Empire and the Early Turkish Republic (Houndmills: Palgrave Macmillan, 2011), 58-59. 
Another perhaps equally far-fetched attempt expressed the sorrow that children allegedly felt at having to say goodbye to their schools at the start of the summer holidays. In one children's reader from the 1940s a child is made to pen a letter to the beloved institution. It begins: "Dear School, We are parting. There are tears in our eyes and a strange feeling of sorrow in our hearts $[. ..] .^{\prime 9}$ To our eyes these words may seem strange indeed, or at least wishful thinking, but they are typical of the no doubt well-intentioned if somewhat pathetic attempts to demonstrate idealized behavior to young readers that formed a prominent element in the construction of the saccharine, idealized fantasy of the world of bonbons.

\section{Bayonets}

By contrast, the depiction of childhood as something startlingly grounded in real-world concerns is referred to here as the world of 'bayonets.' In this realm we encounter children who are not only firmly situated in the grown-up world from which they were often excluded in the 'bonbon' realm but also heavily engaged with it. Far from being sheltered from the worrying developments of the outside world, children in this realm appear affected by both such 'real world' events and phenomena as war, economic competition and the need for national uplift and progress, and are depicted as being actively involved in efforts aimed at improving both their own lot in life and the standing of their country. ${ }^{10}$ In some cases the actions of children are described in these materials as being crucial to the prosperity — and even the survival — of the empire or nation itself.

The dualism between the world of bonbons and that of bayonets is discernible in all sub-periods from the 188 os to the 1930 s but the balance becomes noticeably more weighted in favor of the realm of the bayonet during periods of crisis, and especially after 1911. From that year the Ottoman Empire entered into a succession of wars, first the Italian or Libyan War [Trablusgarp Harbi], then the Balkan Wars (1912-1913), followed by the First World War (1914-1918)

9 Muallim Cevdet [İnanç], Çocuklar için... Hayat bilgisine uygun yazılar ve temsiller ([Balıkesir]: Türk Dili, 1943), 24.

10 Interestingly, in parallel but separate contexts Ottoman children were being encouraged to pursue education in order to serve their own 'nations' or 'races,' what we would today call ethnic or religious groups. Many of these groups used the purportedly essential differences between groups as a spur to encourage striving for success. For a good example, see Duygu Köksal's description of Demetra Vaka (this volume). 
and finally the Greek invasion and 'National Struggle' which ultimately resulted in the founding of the Turkish Republic in 1923. As might be expected under these extremely trying circumstances, the depiction of children could change dramatically to reflect the altered circumstances of the period and especially the adoption of a seemingly permanent war footing. In general terms we can notice a trend to portray children as much more independent, a virtue born of the necessity of coping with the increasingly trying 'demands of the present.' But their independence needed to be subordinate to imperial/national interests. They needed to be resourceful but also obedient, independent but also orderly, on time and clean. ${ }^{11}$ They needed to be curious and intelligent but also to conform to a long list of positive attributes that were drawn up by adults.

Modelling a range of practical activities was the result of this approach. For example, children were depicted as being taught to work, to save money and to serve their country, first the Ottoman Empire and then after 1923 the Turkish Republic. One story from 1909 combined these two goals by telling the exemplary tale of a group of male students who had pooled their resources to start a company. Standing before a model of a steamship, the story's protagonist and the boys' teacher tells his students of another group of boys from the same school who had formed a business partnership fifteen years earlier. By saving their pocket money instead of spending it on sweets or entertainment, their predecessors had saved enough to present their school with the very model that stood before the present-day students of 19og. But, the teacher continued, their partnership did not end when they left school but rather flourished as they made their way into business. Eventually they were able to buy a real steamship that was to be the first of many in their successful foray into the world of commerce; their firm was held up before the rapt fictional audience as evidence of the power of partnership, common endeavour, technology and patriotic service. ${ }^{12}$ In these texts, the very point of childhood and education in particular is to contribute to the nation and, in its more extreme expressions, actually to save it by taking up arms, as we shall shortly see.

In contrast to the serenely oblivious approach of the world of bonbons, the mindset of the world of the bayonet brought politics to the fore. Political actors appear prominently in these texts. The first to appear were the last Ottoman sultans before they eventually give way to Mustafa Kemal, who assumes a

11 On the important role of punctuality and hygiene in late Ottoman approaches to schoolage children, see Avner Wishnitzer, "Teaching Time: Schools, Schedules and the Ottoman Pursuit of Progress," New Perspectives on Turkey 43, 2010, 5-32.

12 Tüccarzâde İbrahim Hilmi, Altın Kitab: Çocuklara ilk kıraat (Istanbul: Kitabhane-i Askeri, 1327 [1909-1910]), 35-37. 
remarkably conspicuous place in the children's literature of the early Republican period as, indeed, he did in society at large. Beyond political leadership, everyday concerns associated with warfare, hardship, suffering and the application of effort and persistence are the hallmarks of this milieu, which often seems unrecognizable by contrast with the world of dolls, toys and frivolity. This is part of a general trend towards representing the 'real world' of politics, geography and adult concerns to children.

The school played an important role in defining this world as well. Increasingly represented as a microcosm for the political community-first the empire and then the nation - the educational institution was a crucial site in modelling an array of new behaviors and attitudes. These could assume an increasingly political function, particularly in the early Republican period when educational change played a crucial part in the Kemalist 'revolution.' But they were part of a longer trend towards the politicization of education that had begun in the late Ottoman period. In the last decades of the imperial era, we begin to see visual representations of the Ottoman sultan appearing in children's textbooks, first in the form of the royal coat of arms, ${ }^{13}$ and then portraitlike illustrations, ${ }^{14}$ along with maps of the Empire. Alongside them appeared messages underscoring the importance of such qualities as obedience to those in authority, respect for one's elders, thrift and service to the Empire. This tendency, with some important adjustments, was continued and, indeed, considerably amplified in the period of the Turkish Republic. It now showcased the role of Mustafa Kemal, soon to be renamed 'Atatürk,' who assumed the role of Educator-in-Chief [Başöğretmen] as one of his myriad public personae. Atatürk's image appeared regularly in textbooks and magazines intended for children in this period. Typical of the paternal image fostered in such publications was that of Atatürk teaching the new alphabet from 1928. While he was depicted as teaching the new script to the full range of the population, images of him teaching the new letters to a child in his lap were particularly prominent. ${ }^{15}$ But it is important to remember that children's publications from both the late Ottoman and early Republican period enlisted a wide range of eminent

13 Çocuklara Rehber 20, 5 Rebiülahr 1315/21 Ağustos 1313 [September 3, 1897], 1.

14 Ali İrfan, Birinci Kıraat (Istanbul: İkbal Kütüphanesi/Şems Matbaasi, 1328-1330 [1910-1912]), 5.

15 Yasemin Gençer, Chris Gratien and Emily Neumeier, "Child and Nation in Early Republican Turkey," Ottoman History Podcast, 102, April 19, 2013. Available online: http://www. ottomanhistorypodcast.com/2013/04/childhood-family-press-turkish-nationalismrepublic.html (See, in particular, the cover illustrations for various magazines from the early Republican period depicting a variety of paternalistic representations of the new republic as personified by Mustafa Kemal). 
political, military and literary figures of the time, such as Ziya Gökalp, Mehmet Fuat Köprülü, Mehmed Emin, Ömer Seyfettin and Kâzım Karabekir, whose writings feature prominently in the children's readers and textbooks from the era, reflecting the seriousness with which officialdom took the humble task of teaching children to read.

The ultimate expression of the world of the bayonet appears in the form of the militarization of childhood, especially from 1911 onwards. The Italian invasion of Ottoman Libya and the subsequent war there was a conflict that, however asymmetrical and however brief, had important implications for the conceptualization of the Ottoman/Turkish nation. ${ }^{16}$ The shores of Libya may have seemed remote to many in the Ottoman heartlands, but the outbreak of the Balkan Wars in 1912 brought the reality of military conflict much closer to home; the Empire's heartlands responded by adopting a martial footing. Public rallies and demonstrations, increasingly desperate news from the front conveyed by an increasingly prominent press, the physical presence of long lines of refugees with their oxcarts in Istanbul, and the overall economic crisis underscored the proximity of the conflict. With the outbreak of the First World War, the militarization of Ottoman society took on unprecedented dimensions. ${ }^{17}$ For many, the end of that brutal conflict, in which Ottoman mortality rates made the Western Front seem almost benign, brought little relief. The occupation and invasion of Anatolia by a combination of forces, including the French in southeastern Anatolia and the Greeks in the west, occasioned armed resistance and in many areas outright civil war. ${ }^{18}$

The succession of wars and the resulting militarization of Ottoman society affected children in a variety of ways. Most apposite to this discussion of the messages with which children were confronted as they learned to read was the conflation of education and warfare. The blurring of the lines between the civilian and military duties and responsibilities expected from and modelled for children took a variety of forms. The subtler, or more nearly subtle, methods included framing educational activities such as reading in an imperial or national context. Illustrations increasingly captured students in patriotic poses, whether depicting a child reading in a setting in which the national flag

16 Murat Belge, "Genç Kalemler and Turkish Nationalism," in Celia Kerslake, Kerem Öktem and Philip Robins (eds), Turkey's Engagement with Modernity: Conflict and Change in the Twentieth Century (Houndmills: Palgrave Macmillan, 2010).

17 Yiğit Akın, "The First World War and the Ottoman Empire: The Home-Front Perspective," paper presented to the soAs Seminars on Turkey, London, March 8, 2013.

18 For a recent account of this period, see Ryan Gingeras, Sorrowful Shores: Violence, Ethnicity, and the End of the Ottoman Empire, 1912-1923 (New York: Oxford University Press, 2009). 
is draped across the top of the picture ${ }^{19}$ or playing football on a field in which the flag flies from a pole situated behind the goal in the background of the image on a magazine's cover. ${ }^{20}$ In contrast to the lack of context displayed in the world of the bonbons, the land of bayonets ensured that real-time national referents were increasingly common in the depictions of children and their activities, even if these were only subtly incorporated.

Most efforts to infuse childhood with a military ethos were, unsurprisingly perhaps, much more direct, sometimes jarringly so. Consider the poem entitled "You'll Be a Soldier" [Asker olacaksin]. Accompanied by an illustration of a toddler marching with a rifle while holding the reins of a toy horse on wheels (Figure 7.1), the poem mixes together the worlds of childhood and the military. The poem reads:

Now shoulder your rifle, mini mini

But tomorrow the game will end

They'll say to you: Move out, soldier!

On your shoulders, pack and rifle... ${ }^{21}$

The shift from the realm of innocent play to deadly fighting is abrupt and even rather surreal.

Other poems presented for child readers are still more direct. The poem that appears under the illustration mentioned above in which the flag frames the reading child, a work entitled "Mektepli" [The student] by the "national poet" Mehmet Emin (Yurdakul), manages to combine bellicosity with zeal for learning:

Friend!

I am a little soldier:

I have that blood in my veins;

My eyes gleam with that fire;

I also want to wage war;

- $\mathrm{O}$ child, what is your strength?

-Knowledge!

My pen will be my weapon,

My book will serve as my fort;

19 Mehmed Fuad Köprülüzâde, Cumhuriyet Çocuklarına Yeni Millî Kıraat (Istanbul: Kanaat Kitaphanesi, 1926), 86.

20 Bizim Mecmua 18, 3 Ağustos 1922.

21 Seracettin [Hisaroğlu], Çocuk Kitabı: Kolay Kıraat (İlk mektep - İkinci sınıf) (Istanbul: Kütüphane-i Hilmi, 1341 [1925]), 51 . 


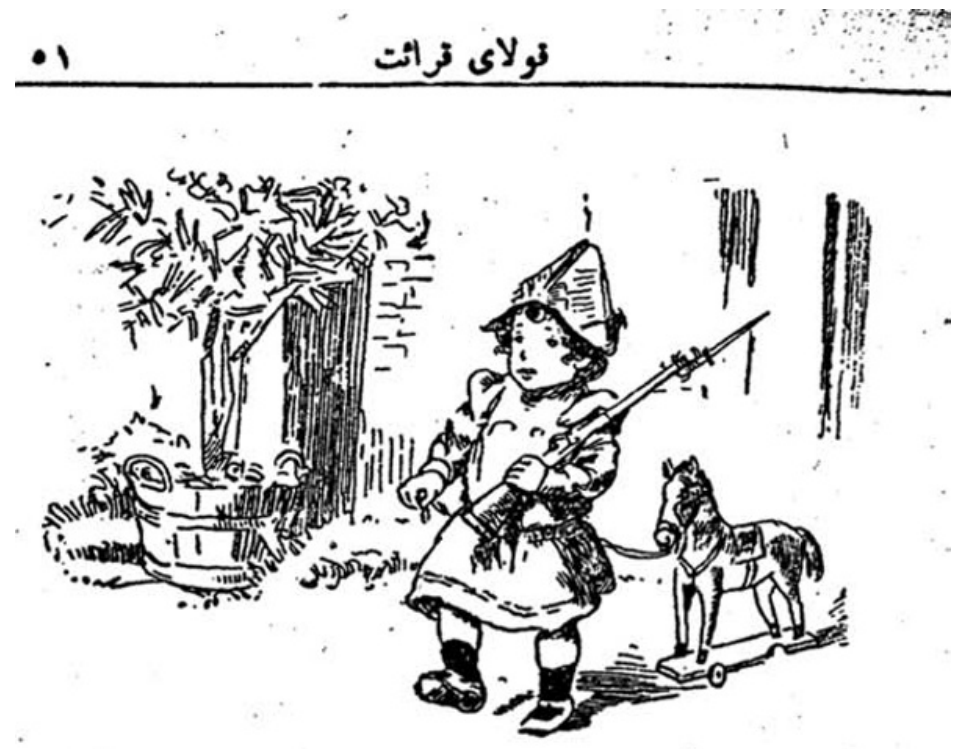

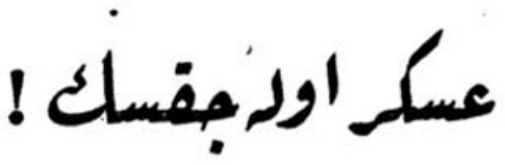

$$
\begin{aligned}
& \text { شُمدى "خته تفنكن } \\
& \text { إوموزلارسنك، مِنى مينى! } \\
& \text { فتط لإزيخ اوبون .ينز؛ } \\
& \text { سكا د.رلر :. هابدى عسك, ! } \\
& \text { اوموز كده جانطه } 6 \text { تقنك } 6 \\
& \text { تعينكا ... .وزده فش:ك ؛ }
\end{aligned}
$$

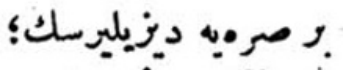

$$
\begin{aligned}
& \text { ورك آلتنده أزيلونك } \\
& \text { دره } 6 \text { ته دئ :ورور } \\
& \text { آتهلبرسك دوثشان كورد }
\end{aligned}
$$

FIGURE 7.1 Illustration for the poem "You'll Be a Soldier" 
My days will be full of conquests;

In every place I will be at the front.

- $\mathrm{O}$ soldier, who is your enemy?

- Ignorance. ${ }^{22}$

Some texts presented war and its destructive power in much more concrete terms. One children's magazine called its readers' attention to the devastation that resulted from the War of Independence. Describing the effects of the war on Western Asia Minor, what had been "the most prosperous regions of Anatolia," the magazine's editor referred to it as having been turned into "a heap of ashes." He describes how he wept at the site before cursing the "vile and despicable enemy" but then in a dramatic twist links the recovery of the nation to the very children he is addressing: "You are the ones whose minds and efforts will rebuild the nation. All of our hopes rest with you. Work, my dears." 23 The connection between education and militarization became even more concrete as the Turkish Republic both continued to use schools as a vehicle for infusing a martial spirit among its youth and used the army as an institution to educate the broader public, as underscored by the phrase that the government publicized on posters that said, "The Army is the People's School" [Ordu Bir Halk Mektebidir]. ${ }^{24}$

It is important to note the heavily gendered way in which children's wartime duties are presented. Girls are expected to help out in the domestic sphere, by working with their mothers. Female literacy is valued mainly for its ability to enable girls to write letters to absent soldier fathers while boys drill and prepare to take up arms for the nation. In one representative children's reader from the early Turkish Republican era, all children are encouraged to love their flag and pay reverence to Mustafa Kemal — the headmaster of the nation — but the roles are quite gender-specific. Boys are represented playing a variety of martial games (marching, shouldering rifles, etc.) while the girls are seen to be taking care of domestic duties (sewing, cleaning, etc.). Girls are shown to employ their educational attainments in a supporting role. A frequent trope is for the good girl, after finishing her housework, to write a letter that will surprise her distant father with her ability to write and therefore to play her part in keeping the nation together during times of turmoil:

22 Köprülüzâde, Cumhuriyet Çocuklarına, 86-87.

23 Yeni Yol 10, 8 Teşrin-i sani 1339 [November 8, 1923], 146.

24 On the subject of the Turkish "martial spirit," see Ayşe Gül Altınay, The Myth of the Military Nation: Militarism, Gender, and Education in Turkey (Houndmills: Palgrave Macmillan, 2004), $29 \mathrm{ff}$. For the relationship between education and militarization, see Ibid., $119 \mathrm{ff}$. 
My dear father, my solider father,

It has been a year since you went away. I am going to school. I am learning to read and write. I am even able to write you this letter.

Your loving daughter Ylldız

\section{Worlds Colliding}

For the most part the two worlds we have been analyzing here remained distinct but occasionally they collided, sometimes jarringly so. Returning to the toy soldier depicted alongside the poem "You'll be a Soldier," we have an image that highlights the incongruity of the two worlds of youthful innocence and adult concerns. The toddler portrayed here is curiously suspended between the world of toys and games, represented by the lead to the pull-toy hobby horse in one hand, and the realm of violence and death, represented by the rifle with its affixed bayonet held in the other, thus fittingly illustrating the conflicted approach to children during this period of flux and, increasingly, of acute societal and political stress. It would not be the first or the last time that childhood and education were drawn into important political battles, of course. We need only think of the tussles over curricular reform waged in both the late Ottoman and Turkish Republican periods or the debates over the headscarf in more recent years to find other prominent examples. What makes the mixed messages presented to children in the materials we have been surveying here particularly noticeable is the clash inherent in the juxtaposition between the two worlds that were otherwise carefully kept apart.

Some of the difficulty, if not downright ineptitude, in finding a balanced approach to children can doubtless be attributed to the novelty of the situation. The popular press and the idea of public education were still relatively new phenomena in the late nineteenth and early twentieth century and authors and publishers were struggling to come to terms with how to address children and with finding the appropriate content to offer the new but growing constituency of - and market for-the young reading public. ${ }^{25}$ In attempting to find the right balance, publishers adopted a variety of modes of address, ranging from the patronizing to the collegial and even at times the conspiratorial. ${ }^{26}$ There were also many attributes that linked the two worlds. They both

25 For more detail, see Fortna, Learning to Read.

26 For examples of children's publications attempting to forge an alliance against the teacher, see Fortna, Learning to Read, $148 \mathrm{ff}$. 
shared important common attitudes towards their child audience, such as the frequently overweening didacticism inherent in their approach to children and the distrust of larger social milieus outside the confines of the controlled classroom or the carefully concocted text.

But as we have seen, the contrasts between the two worlds could on occasion be remarkably sharp. When these worlds collided the result could appear stark. For example, an early Republican-era children's magazine cover featured an illustration of a girl teaching Turkish to her dolls and stuffed animals. Next to a caption which reads "Teacher Nebahat gives a lesson in Turkish," the young girl appears to be earnestly engaged in teaching a class composed of her assembled dolls and playthings, some of which are seated on miniature chairs. Outside of the frame the stern visage of Mustafa Kemal Paşa in military attire surveys the scene. This is yet another image that neatly encapsulates the tension between the serious and the frivolous at work in children's literature from this period. ${ }^{27}$ Even the cloistered activity of a child playing with her toys could be confronted, even in pictorial form, with the adult world of politics and nation, thereby producing an odd juxtaposition.

From the perspective of the children, for whom after all these messages were intended, it must have been puzzling indeed to negotiate the dichotomy between these two worlds. Young readers were confronted with a variety of mixed messages. The political ones were perhaps the most obvious. For example, child readers in the last years of the Ottoman Empire were encouraged to devote themselves to the Empire and its sultan. ${ }^{28}$ It was not long, however, before they were being encouraged to curse the former Ottoman ruler and to despise the Empire almost as soon as it had been replaced. ${ }^{29}$ More coherent were the intended contrasts put before children to reinforce behavioral or moral lessons. The juxtaposition between the good child and the bad child was a standard trope in the literature produced for children - and one of the chief reasons for its rather stilted approach. The prolific late Ottoman writer Ahmed Midhat Efendi virtually made a career out of the didactic style evident in his Terbiyeli Çocuk [The Well-behaved Child], ${ }^{30}$ published in the mid-188os, which juxtaposes a well-behaved and a naughty child. Other publications picked up on this theme. One item in a children's magazine from the very early Republican period contrasted a lazy child with his hardworking counterpart. ${ }^{31}$ The lazy

27 Yeni Yol 46, 16 Teşrin-i evvel 1340 [October 16, 1924].

28 See, for example, İrfan, Birinci Kıraat, 8.

29 See, for example, Köprülüzâde, Cumhuriyet Çocuklarına, 3.

30 Ahmed Midhat Efendi, Terbiyeli Çocuk (İstanbul: Kırkanbar, 1303 [1885-1886]).

31 Yeni Yol 20, 17 Kanunusani 1340 [17 January 1904], 275. 
child has lost everything while his poor, hardworking opposite made something of himself. Another version of this theme was to contrast the literate child with his or her illiterate twin. The former is a happy child who receives presents from his relatives, reads stories to his parents after helping them with the housework and is given money to buy books, while the latter ignores his teachers who punish him, is scolded by his mother for his disobedience and locked in a cupboard for good measure. ${ }^{32}$

The question of how children responded to these mixed messages would require additional research but we can hazard a guess that the responses would have been diverse. It seems likely that some children were eager to join the world of the bayonet while others were content to remain in the safe but illusory world of bonbons. What seems clear is that in their groping for ways to speak to the young, the adults of the rapidly shifting late Ottoman and early Turkish Republican periods attempted to establish a series of clear pedagogical contrasts. This chapter has focused on the juxtaposition of the protected with an engaged conception of childhood in order to highlight one of the many such distinctions being drawn for children in this period. Other examples include the contrasts between good against bad, new against old, Western against Oriental or secular against religious. But children have always been forced to accommodate and overcome the inconsistencies of adults. The transition from Ottoman Empire to the Turkish Republic was perhaps only a rather exaggerated case of the mixed messages with which children are confronted all the time.

\section{Bibliography}

\section{Primary}

Celal, Sadrettin, Cümhuriyet Çocuklarına Sevimli Kırâat, Istanbul: Kanaat Kütüphanesi, 1928.

Cevdet [İnanç], Muallim, Çocuklar için...Hayat bilgisine uygun yazılar ve temsiller, [Balıkesir]: Türk Dili, 1943 .

Hilmi, Tüccarzâde İbrahim, Altın Kitab: Çocuklara ilk kıraat, Istanbul: Kitabhane-i Askeri, 1327 [1909-1910].

İrfan, Ali, Birinci Kıraat, Istanbul: İkbal Kütüphanesi/Şems Matbaası, 1328-1330 [1910-1912].

Köprülüzâde, Mehmed Fuad, Cumhuriyet Çocuklarına Yeni Millı̂ Kıraat, Istanbul: Kanaat Kitaphanesi, 1926.

32 Ali Nazima, Oku yahud yeni risale-i ahlâk ve vezaif-i etfal (Istanbul: Kasbar Matbaası, 1320 [1902-1903]), $4 \mathrm{ff}$. 
Midhat Efendi Ahmed, Terbiyeli Çocuk, İstanbul: Kurkanbar, 1303 [1885-1886].

Nazima, Ali, Oku yahud yeni risale-i ahlâk ve vezaif-i etfal, Istanbul: Kasbar Matbaası, 1320 [1902-1903].

Seracettin [Hisaroğlu], Çocuk Kitabı: Kolay Kıraat (Istanbul: İbrahim Himli, 1925).

\section{Journals}

Bizim Mecmua.

Çocuklara Rehber.

Gürbüz Türk Çocuğu.

Yeni Yol.

\section{Secondary}

Akın, Yiğit, "The First World War and the Ottoman Empire: The Home-Front Perspective," paper presented to the SOAS Seminars on Turkey, London, March 8, 2013.

Altınay, Ayşe Gül, The Myth of the Military Nation: Militarism, Gender, and Education in Turkey, Houndmills: Palgrave Macmillan, 2004.

Ariès, Philippe, Centuries of Childhood: A Social History of Family Life, translated by Robert Baldick, New York: Vintage, 1962.

Belge, Murat, "Genç Kalemler and Turkish Nationalism," in Celia Kerslake, Kerem Öktem and Philip Robins (eds), Turkey's Engagement with Modernity: Conflict and Change in the Twentieth Century, Houndmills: Palgrave Macmillan, 2010.

Brummett, Palmira, Image and Imperialism in the Ottoman Revolutionary Press, 1908-19n, Albany, NY: SUNY Press.

Cunningham, Hugh, Children and Childhood in Western Society since 1500, London: Longman, 1995 .

Fortna, Benjamin C., Learning to Read in the Late Ottoman Empire and the Early Turkish Republic, Houndmills: Palgrave Macmillan, 2011.

Gençer, Yasemin, Chris Gratien and Emily Neumeier, "Child and Nation in Early Republican Turkey," Ottoman History Podcast, 102, April 19, 2013. Available online: http://www.ottomanhistorypodcast.com/2013/04/childhood-family-press-turkish -nationalism-republic.html.

Gingeras, Ryan, Sorrowful Shores: Violence, Ethnicity, and the End of the Ottoman Empire, 1912-1923, New York: Oxford University Press, 2009.

Jenks, Chris, Childhood, 2nd edition, London: Routledge, 1996.

Kreiser, Klaus, and Patrick Bartsch (eds.), Türkische Kindheiten, [Frankfurt am Main:] Literaturca, 2012.

Wishnitzer, Avner, "Teaching Time: Schools, Schedules and the Ottoman Pursuit of Progress," New Perspectives on Turkey 43, 2010, 5-32. 